\title{
A phylogenetic effect on strontium concentrations in angiosperms
}

\author{
Neil Willey*, Kathy Fawcett \\ Centre for Research in Plant Science, Faculty of Applied Sciences, University of the West of England, Frenchay, Bristol BS16 1QY, UK
}

Received 21 February 2005; accepted 8 June 2005

\begin{abstract}
A Residual Maximum Likelihood (REML) procedure was used to compile Sr concentrations in 103 plant species from experiments with Sr concentrations in 66 plant species from the literature. There were 14 species in common between experiments and the literature. The REML procedure $\log _{\mathrm{e}}$-transformed data and removed absolute differences in $\mathrm{Sr}$ concentrations arising from soil factors and exposure times to estimate mean relative $\mathrm{Sr}$ concentrations for 155 species. One hundred and forty-two species formed a group with a normal frequency distribution in mean relative Sr concentration. A nested hierarchical analysis of variance (ANOVA) based on the most recent molecular phylogeny of the angiosperms showed that plant species do not behave independently for $\mathrm{Sr}$ concentration but that there is a significant phylogenetic effect on mean relative $\mathrm{Sr}$ concentrations. Concentrations of $\mathrm{Sr}$ in non-Eudicots were significantly less than in Eudicots and there were significant effects on $\mathrm{Sr}$ concentrations in the dataset down the phylogenetic hierarchy to the family level. Of the orders in the dataset the Cucurbitales, Lamiales, Saxifragales and Ranunculales had particularly high Sr concentrations and the Liliales, Poales, Myrtales and Fabales particularly low Sr concentrations. Mean relative Sr concentrations in 60 plant species correlated with those reported elsewhere for Ca in the same species, and the frequency distribution and some phylogenetic effects on $\mathrm{Sr}$ concentration in plants were similar to those reported for Ca. This analysis of mean relative Sr concentrations in 155 plant species across the angiosperm phylogeny might be helpful for modelling ${ }^{90} \mathrm{Sr}$ in food chains, predicting radiological doses to flora, and selecting species for phytomonitoring and phytoremediation of ${ }^{90} \mathrm{Sr}$.
\end{abstract}

(C) 2005 Published by Elsevier B.V.

Keywords: Strontium; Phylogeny; Radioecology; Calcium; Phytoremediation

\section{Introduction}

${ }^{90} \mathrm{Sr}$ is amongst the most radioecologically significant isotopes released into terrestrial ecosystems (Kliashtorin et al., 1994). It is a chemical analogue of $\mathrm{Ca}$ which is accumulated by microbes, plants and animals to fulfil essential physiological functions (White and Broadley, 2003). The 28.8 year half-life and high energy $\beta$-emissions of ${ }^{90} \mathrm{Sr}$ mean that it can be a significant long-term radiological hazard to the biosphere. ${ }^{90} \mathrm{Sr}$ is available to the soil solution in almost any mineral soil it contaminates (Frissel, 1992), transport is rapid (Kliashtorin et al., 1994), and transfer to plants high (Ban-nai and Muramatsu, 2002). In the Khyshtym accident zone ${ }^{90} \mathrm{Sr}$ is the most common contaminating radioisotope (Karavaeva et al., 1994; Tikhomirov and Shcheglov, 1994) and in the Chernobyl exclusion zone ${ }^{90} \mathrm{Sr}$ is a significant contributor to

\footnotetext{
* Corresponding author. Tel.: +44 177 3442314; fax: +44 1173442904

E-mail address: Neil.Willey@uwe.ac.uk (N. Willey).
}

radioactive contamination (Anspaug et al., 1988; Kashparov et al., 1999). ${ }^{90} \mathrm{Sr}$-contaminated land also occurs at some nuclear test sites (e.g. Walker et al., 1997) and nuclear facilities (e.g. Poston et al., 1998). Routine releases from nuclear facilities frequently contain some ${ }^{90} \mathrm{Sr}$, and there is much ${ }^{90} \mathrm{Sr}$ in nuclear waste. Understanding soil-to-plant transfer of ${ }^{90} \mathrm{Sr}$ is critical to understanding its behaviour in terrestrial ecosystems, and therefore, to environmental assessments of accidental releases, to monitoring regimes, and to environmental impact assessments of nuclear waste disposal programmes. It has also long been clear that increases of two- or three-fold in plant uptake of ${ }^{90} \mathrm{Sr}$ might make it possible to decontaminate soils of ${ }^{90} \mathrm{Sr}$ using plant uptake (Romney et al., 1957; Nishita et al., 1958; Fuhrmann et al., 2002). Soil properties clearly affect soil-to-plant transfer of ${ }^{90} \mathrm{Sr}$ (Abbazov et al., 1978; Roca et al., 1997; Askbrant and Sandalls, 1998) but differences between plant species in uptake from the same soil have also long been known to make a significant contribution to differences in soil-to-plant transfer (Andersen, 
1967; Garret et al., 1971; Veresoglou et al., 1995). Here, we present a phylogenetic analysis of inter-species differences in $\mathrm{Sr}$ concentrations in plants.

Molecular phylogenetics and improved algorithms for inter-taxa comparisons are transforming our understanding of the evolutionary history of the living world (Sugden et al., 2003). There are now available new phylogenies of the angiosperms (Soltis et al., 1999; Kuzoff and Gasser, 2000; APGII, 2003). Many inter-species comparisons, and the statistics they are based on, assume that species are independent sampling units (Ackerley, 1999). The mapping of interspecies comparisons to new phylogenies of flowering plants shows that this assumption is frequently violated (Harvey et al., 1996; Ackerley, 1999), i.e. numerous inter-species comparisons reveal a phylogenetic effect on phenotype. Not only have phylogenetic effects been described in plant phenotypes such as photosynthetic pathway (Ehleringer and Monson, 1993), carnivory (Albert et al., 1992), N-fixing symbioses (Doyle, 1998), mycorrhizal symbioses (Fitter and Moyerson, 1996) and ecological traits (Ackerley, 1999), but also in the uptake of ${ }^{134 / 137} \mathrm{Cs}$ (Broadley et al., 1999; Willey et al., 2005), heavy metals (Broadley et al., 2001), Al (Jansen et al., 2002), $\mathrm{Ca}$ (Broadley et al., 2003) and a range of nutrients (Broadley et al., 2004). It has been noted that phylogenies might be useful to estimating radionuclide transfer to plants (Beresford et al., 2004; Willey et al., 2005). Sr concentrations in different plant species are an inter-species comparison yet to be analysed phylogenetically. Such an analysis might be useful given that post-Chernobyl studies clearly revealed the importance of a range of species in semi-natural ecosystems to dose assessment models (Desmet et al., 1990), there is increasing focus on radiological dose assessments to a range of flora (Strand and Larsson, 2001) and growing interest in finding plant species that might optimise phytoextraction of ${ }^{90} \mathrm{Sr}$ (Willey et al., 2001).

${ }^{90} \mathrm{Sr}$ 's chemical analogue $\mathrm{Ca}$ is a plant macronutrient. $\mathrm{Ca}$ is accumulated from the soil solution into shoots through a combination of symplastic pathways mediated by $\mathrm{Ca}$ channels (White, 1998) and apoplastic pathways (White, 2001). Angiosperm shoot $\mathrm{Ca}$ concentration generally varies between 0.1 and $5 \%$ on a dry weight basis (Marschner, 1995). Dicots have long been thought to accumulate $\mathrm{Ca}$ to higher concentrations than monocots, at least partly because of the higher cation exchange capacity of their roots (White and Broadley, 2003). Broadley et al. (2003), using a new angiosperm phylogeny, showed that there was a significant phylogenetic effect on angiosperm shoot $\mathrm{Ca}$ content and that Eudicots tend to accumulate $\mathrm{Ca}$ to higher concentrations than the Commelinid Monocots. Much inter-taxa variation in Ca content occurred at the level of order and above, with the orders Cucurbitales, Brassicales, Malvales and Rosales having with the highest $\mathrm{Ca}$ content.

Broadley et al. (2003) demonstrated the importance that phylogenetic effects in the variation of $\mathrm{Ca}$ concentration in angiosperms might have for predicting transfer coefficients and managing human dietary intakes of $\mathrm{Ca}$. Given that $\mathrm{Ca}$ and
$\mathrm{Sr}$ are known to behave similarly during soil-to-plant transfer (Andersen, 1967; Veresoglou et al., 1995, 1996), we hypothesised that there is a phylogenetic effect on $\mathrm{Sr}$ concentrations in plants and that this might be useful for predicting transfer coefficients, managing dietary intakes and selecting plants for phytoextraction of ${ }^{90} \mathrm{Sr}$. Here, using the same statistical methods as Broadley et al. (2003), we report an analysis for 103 taxa we grew and 66 taxa from the literature, that quantifies a phylogenetic effect on $\mathrm{Sr}$ content of angiosperms and compares it to that of $\mathrm{Ca}$.

\section{Methods}

Literature reports of inter-species comparisons in $\mathrm{Sr}$ concentrations of any isotope were compiled with data we generated for ${ }^{85} \mathrm{Sr}$ using the Residual Maximum Likelihood (REML) procedure of Broadley et al. (1999, 2001, 2003, 2004). Nine publications were identified that reported, without the possibility of foliar contamination, a comparison of concentrations of a Sr isotope in green shoots in two or more plant species growing on the same substrate under identical conditions. In five of these, more than one comparison was reported (e.g. from different soil types or with different levels of additives to soil). These were treated as separate studies in the REML to give 45 studies in total, including 66 species, from the literature (Table 1). Different isotopes of Sr were used in different studies but were all included in the database on the assumption that plants did not discriminate between isotopes of Sr. Plant exposure times to $\mathrm{Sr}$ in literature studies varied from days to weeks but might all be classified as 'chronic exposure' although in no instance was it established that uptake had reached steady-state.

One hundred and three species, chosen to complement those in literature studies by increasing the taxonomic spread across comparisons, were radiolabelled with ${ }^{85} \mathrm{Sr}$. Five replicate pots of each species, with approximately $250 \mathrm{~g}$ of Levingtons's F2 (Fisons, Ipswich, UK) per pot, were grown in a greenhouse for approximately 7 weeks in $16 \mathrm{~h}$ day and $8 \mathrm{~h}$ nights at c. 24 and $16^{\circ} \mathrm{C}$, respectively. Plants were labelled with ${ }^{85} \mathrm{Sr}$ in the exponential phase of their growth and before they flowered, hence some species were slightly younger or older than 7 weeks. Species chosen were primarily fast growing and herbaceous but also included as wide a range of food crops as practicable. Plants were watered on demand up to the day before labelling. Plants were radiolabelled by putting $50 \mathrm{ml}$ of $250 \mu \mathrm{M} \mathrm{SrCl}_{2}$ (radiolabelled with $1110 \mathrm{kBq}^{-1}{ }^{85} \mathrm{Sr}$ ) evenly onto the substrate surface. This saturated the substrate, ensured homogenous distribution and produced a small volume of excess radiolabelled solution which was prevented from escaping from the pots by saucers. Excess solution in saucers was reabsorbed during the labelling period in all instances. Plants were harvested after $3 \mathrm{~h}$, approximately $1 \mathrm{~cm}$ above the substrate surface, weighed fresh, dried for at least $48 \mathrm{~h}$ at $80^{\circ} \mathrm{C}$, weighed dry, ground and a weighed amount analysed for ${ }^{85} \mathrm{Sr} \gamma$-emissions in an LKB 
Table 1

Mean relative concentrations from REML analysis for 155 plant species from 58 studies according to the Angiosperm Phylogeny Group classification (APG, 2003)

\begin{tabular}{|c|c|c|c|c|c|c|c|c|}
\hline Class & Subclass & Group & Superorder & Order & Genus and species & Common name & $\begin{array}{l}\text { Mean relative } \\
\text { concentration }\end{array}$ & Study \\
\hline \multirow{45}{*}{ Non-Eudicots } & \multirow{7}{*}{ Magnoliids } & & \multirow[t]{7}{*}{ Magnoliids } & \multirow[t]{3}{*}{ Piperales } & Peperomia hederaefolia & Ivy Peperomia & 4.35 & 5 \\
\hline & & & & & Peperomia rotundifolia & $\begin{array}{l}\text { Round-lvd } \\
\text { peperomia }\end{array}$ & 3.58 & 12 \\
\hline & & & & & Houttynia cordata & Houttynia & 3.01 & 1 \\
\hline & & & & Magnoliales & Michelia maudiae & Michelia & 3.30 & 3 \\
\hline & & & & \multirow[t]{3}{*}{ Laurales } & Calycathus floridus & Carolina Allspice & 2.22 & 2 \\
\hline & & & & & Calycathus occidentalis & $\begin{array}{l}\text { Western spice } \\
\text { bush }\end{array}$ & 3.74 & 3 \\
\hline & & & & & Chimonanthus praecox & Wintersweet & 3.21 & 4 \\
\hline & \multirow[t]{38}{*}{ Monocots } & & \multirow[t]{9}{*}{ Non-Commelinids } & \multirow[t]{3}{*}{ Asparagales } & Crocosmia masonorum & Montbretia & 1.43 & 5 \\
\hline & & & & & Tigridia pavonia & Peacock flower & -0.01 & 6 \\
\hline & & & & & Asparagus officinalis & Asparagus & 2.21 & 13 \\
\hline & & & & Dioscorales & Dioscorea japonica & Yam & 4.48 & 1 \\
\hline & & & & \multirow[t]{5}{*}{ Liliales } & Allium ameloprasum & Wild Leek & 3.08 & 3 \\
\hline & & & & & Allium сера & Onion & 0.62 & $\begin{array}{l}3,13 \\
57\end{array}$ \\
\hline & & & & & Allium porrum & Leek & -0.50 & 57 \\
\hline & & & & & Allium scheonoprasum & Chives & -0.35 & 3,57 \\
\hline & & & & & Allium tuberosum & Garlic chives & 2.85 & 4 \\
\hline & & & \multirow[t]{29}{*}{ Commelinids } & \multirow[t]{2}{*}{ Arecales } & Areca lutescens & Areca palm & 3.41 & 1 \\
\hline & & & & & Phoenix dactylifera & Date & 0.57 & 5 \\
\hline & & & & Commelinales & Commelina coelestris & Blue spiderwort & 3.87 & 1 \\
\hline & & & & \multirow[t]{26}{*}{ Poales } & Carex comens & Bronze sedge & 4.95 & 7 \\
\hline & & & & & Carex stricta & Tussock Sedge & 1.80 & 4 \\
\hline & & & & & Cyperus 'Zumila' & Cyperus & 4.01 & 1 \\
\hline & & & & & Agrostis capillaries & Common Bent & 2.96 & $49-55$ \\
\hline & & & & & Anthoxanthum odoratum & $\begin{array}{l}\text { Sweet Vernal } \\
\text { Grass }\end{array}$ & 2.58 & $\begin{array}{l}44,46, \\
48-56\end{array}$ \\
\hline & & & & & Avena sativa & Oats & 2.55 & $\begin{array}{l}14,15, \\
36-40, \\
57\end{array}$ \\
\hline & & & & & Cynodon dactylon & Bermuda Grass & 2.70 & 14 \\
\hline & & & & & Cynosaurus cristatus & Cested Dog's Tail & 2.74 & 36,38 \\
\hline & & & & & Dactylis glomerata & Cock's Foot & 2.42 & $43-57$ \\
\hline & & & & & Digitaria decumbens & Pangola Grass & 3.03 & 14 \\
\hline & & & & & Digitaria sanguinalis & Crab Grass & 2.97 & 14 \\
\hline & & & & & Festuca pratense & Meadow Fescue & 2.59 & 57 \\
\hline & & & & & Holcus lanatus & Yorkshire Fog & 2.44 & 49,56 \\
\hline & & & & & Hordeum distichum & Spring Barley & 2.40 & $\begin{array}{l}15 \\
36-40\end{array}$ \\
\hline & & & & & Hordeum sativum & Barley & 2.17 & 57 \\
\hline & & & & & Lolium perenne & Rye grass & 2.92 & $\begin{array}{l}1, \\
43-48, \\
57\end{array}$ \\
\hline & & & & & Oryza sativa & Rice & 2.04 & $\begin{array}{l}20-35, \\
57\end{array}$ \\
\hline & & & & & Panicum miliaceum & Common Millet & 2.05 & 57 \\
\hline & & & & & Paspalum notatum & Bahia Grass & 2.02 & 14 \\
\hline & & & & & Paspalum dilitatum & Dallis Grass & 2.55 & 14 \\
\hline & & & & & Pennisetum typhoides & Pearl Millet & 1.23 & 58 \\
\hline & & & & & Phleum pratense & Timothy Grass & 2.83 & $\begin{array}{l}36-40, \\
57\end{array}$ \\
\hline & & & & & Secale cereale & Rye & 2.38 & 15 \\
\hline & & & & & Sorghum vulgare & Sorghum & 1.31 & 11,58 \\
\hline & & & & & Triticum aestivum & Wheat & 2.58 & $\begin{array}{l}6,15 \\
20-35\end{array}$ \\
\hline & & & & & Triticum durum & Durum wheat & 2.15 & 6 \\
\hline
\end{tabular}


Table 1 (Continued)

\begin{tabular}{|c|c|c|c|c|c|c|c|c|}
\hline Class & Subclass & Group & Superorder & Order & Genus and species & Common name & $\begin{array}{l}\text { Mean relative } \\
\text { concentration }\end{array}$ & Study \\
\hline & & & & & Triticum vulgare & Wheat & 1.65 & 57 \\
\hline & & & & & Zea mays & Maize & 2.03 & 42,57 \\
\hline & & & & Zingiberales & Canna indica & Canna lily & 3.22 & 4 \\
\hline & & & & & Musa ensete & Ethiopian banana & 3.20 & 8 \\
\hline & & & & & Zingiber officinale & Ginger & 0.58 & 5 \\
\hline & & & & Alismatales & Philodendron hastatum & Elephant's Ear & 4.88 & 13 \\
\hline & & & & & Scindapsis aureus & $\begin{array}{l}\text { Philodendron } \\
\text { Devil's Ivy }\end{array}$ & 0.27 & 9 \\
\hline \multirow[t]{39}{*}{ EUDICOTS } & & Basal & & Ranunculales & Papaver pilosum & Hairy poppy & 8.58 & 9 \\
\hline & & & & & Papaver somniferum & Opium poppy & 5.67 & 13 \\
\hline & & & & & Pulsatilla vulgaris & Pasque flower & 4.28 & 9,13 \\
\hline & & & & Proteales & Grevillea robusta & Silk oak & 6.29 & 10 \\
\hline & & Core & & Caryophyllales & Amaranthus retroflexus & Redroot Pigweed & 1.72 & 41 \\
\hline & & & & & Beta vulgaris & Beet & 3.09 & $\begin{array}{l}1,8, \\
57, \\
36-40 \\
57\end{array}$ \\
\hline & & & & & Spinacia oleracea & Spinach & 3.61 & $37-40$ \\
\hline & & & & & Fagopyrum esculentum & Buckwheat & 3.16 & 36,38 \\
\hline & & & & & Rheum tartaricum & Rhubarb & 2.94 & 1 \\
\hline & & & & & Rumex acetosa & Sorrel & 7.33 & 2 \\
\hline & & & & & Rumex crispus & Curled Dock & 2.41 & $43-48$ \\
\hline & & & & & Rumex sanguineus & Bloodwort & 3.27 & 2 \\
\hline & & & & & Dianthus seguiri & Pink & 2.73 & 2 \\
\hline & & & & & Dianthus gratinopolis & Cheddar pink & -1.16 & 3 \\
\hline & & & & & Gypsophila elegans & Baby's tears & 5.40 & 10 \\
\hline & & & & & Gypsophila paniculata & Baby's Breath & 4.02 & 5 \\
\hline & & & & & Silene chalcedonica & Maltese Cross & 9.22 & 8 \\
\hline & & Rosids & Basal & Saxifragales & Bergenia cordifolia & $\begin{array}{l}\text { Heartleaf } \\
\text { Bergenia }\end{array}$ & 8.38 & 13 \\
\hline & & & & & Bergenia purpurescens & Bergenia & 7.27 & 6 \\
\hline & & & & & Heuchera micrantha & Alum-root & 4.77 & 12 \\
\hline & & & & & Heuchera sanguinea & Coral Bells & 5.85 & 2 \\
\hline & & & & Geraniales & Geranium pyrenaicum & $\begin{array}{l}\text { Pyrenian } \\
\text { cranesbill }\end{array}$ & 4.94 & 8,12 \\
\hline & & & & Myrtales & Callistemon subdulatus & $\begin{array}{l}\text { Tonghi } \\
\text { bottle-brush }\end{array}$ & 2.70 & 2 \\
\hline & & & & & Clarkia bottea & $\begin{array}{l}\text { Farewell-to- } \\
\text { Spring }\end{array}$ & 1.51 & 9 \\
\hline & & & & & Oenothera hookeri & $\begin{array}{l}\text { Giant Yellow } \\
\text { evening primrose }\end{array}$ & 2.24 & 3 \\
\hline & & & & & Oenothera tetragona & Evening primrose & 4.41 & 11 \\
\hline & & & Eurosid I & Malpighiales & Hypericum olympicum & $\begin{array}{l}\text { Dwarf St. John's } \\
\text { Wort }\end{array}$ & 4.69 & 5 \\
\hline & & & & & Hypericum perforatum & St. John's Wort & -1.86 & 4 \\
\hline & & & & & Linum usitatissimum & Flax & 2.94 & 2,57 \\
\hline & & & & & Passiflora caerulescens & Passion flower & 8.19 & 5 \\
\hline & & & & & Viola tricolor & Pansy & 3.25 & 1 \\
\hline & & & & Fabales & Anthyllis vulneraria & Kidney Vetch & 4.04 & 57 \\
\hline & & & & & Lotus corniculatus & Bird's Foot Trefoil & 3.61 & $43-57$ \\
\hline & & & & & Lupinus angustifolia & Lupin & 3.73 & 1,6 \\
\hline & & & & & Lupinus luteus & Yellow lupin & 2.97 & 57 \\
\hline & & & & & Medicago lupulina & Black medik & 0.53 & 11 \\
\hline & & & & & Medicago sativa & Alfalfa & 3.51 & $\begin{array}{l}43-48 \\
57\end{array}$ \\
\hline & & & & & Phaseolus acutifolius & Tepary Beans & 4.23 & 41 \\
\hline & & & & & Phaseolus vulgaris & Pinto Beans & 2.71 & 57 \\
\hline
\end{tabular}


Table 1 (Continued)

\begin{tabular}{|c|c|c|c|c|c|c|c|c|}
\hline Class & Subclass & Group & Superorder & Order & Genus and species & Common name & $\begin{array}{l}\text { Mean relative } \\
\text { concentration }\end{array}$ & Study \\
\hline & & & & & Pisum sativum & Peas & 3.87 & $\begin{array}{l}36-40, \\
57\end{array}$ \\
\hline & & & & & Trifolium arvense & Hare's foot clover & 3.70 & 8 \\
\hline & & & & & Trifolium hybridum & Alsike Clover & 3.20 & 57 \\
\hline & & & & & Trifolium repens & White clover & -3.29 & $\begin{array}{l}3,11, \\
14, \\
43-57\end{array}$ \\
\hline & & & & & Trifolium subterranean & $\begin{array}{l}\text { Subterranean } \\
\text { Clover }\end{array}$ & 3.21 & $49-56$ \\
\hline & & & & & Trifolium pratense & Red clover & 3.79 & $\begin{array}{l}6,10, \\
36-40, \\
57\end{array}$ \\
\hline & & & & & Vicia sativa & Commen Vetch & 3.12 & 57 \\
\hline & & & & Rosales & Humulus japonicus & Japanese hop & 5.08 & 12 \\
\hline & & & & & Humulus lupulus & Hop & 5.81 & 6 \\
\hline & & & & & Cannabis sativa & Hemp & 3.73 & 57 \\
\hline & & & & & Elaeagnus multiflora & Cherry Silverberry & 0.74 & 2 \\
\hline & & & & & Maclura pomifera & Osage orange & -0.78 & 7 \\
\hline & & & & & Morus alba & White mulberry & 4.32 & 7 \\
\hline & & & & & Fragaria vesca & Strawberry & 3.61 & $1,3,7$ \\
\hline & & & & & Pilea cadierei & Aluminum Plant & 5.95 & 9 \\
\hline & & & & Cucurbitales & Cucurbita maxima & $\begin{array}{l}\text { Pumpkin 'Blue } \\
\text { Hubbard' }\end{array}$ & 6.01 & 5 \\
\hline & & & & & Cucurbita pepo & Marrow & 6.63 & 3,42 \\
\hline & & & Eurosid II & Brassicales & Alyssum montanum & $\begin{array}{l}\text { Mountain } \\
\text { Madwort }\end{array}$ & 2.79 & 2 \\
\hline & & & & & Alyssum petraeum & Golden Tuft & 5.98 & 9 \\
\hline & & & & & Alyssum saxatile & Basket of Gold & 0.25 & 3 \\
\hline & & & & & Armoracia rusticana & Horseradish & 2.61 & 57 \\
\hline & & & & & Brassica juncea & Indian Mustard & 3.44 & 41 \\
\hline & & & & & Brassica napus & Rape & 1.01 & 57 \\
\hline & & & & & Brassica oleracea & Cabbage & 2.50 & $\begin{array}{l}4,9, \\
36-40, \\
57\end{array}$ \\
\hline & & & & & Brassica rapa & Chinese Cabbage & 3.16 & $16-19$ \\
\hline & & & & & Raphanus sativus & Radish & 2.68 & $\begin{array}{l}16-19, \\
36-40, \\
57\end{array}$ \\
\hline & & & & & Sinapsis alba & White Mustard & 3.34 & $\begin{array}{l}36-40, \\
57\end{array}$ \\
\hline & & & & & Tropaeolum perigrinum & Canary creeper & 5.37 & 5 \\
\hline & & & & Malvales & Cistus palhinhae & St. Vincent Cistus & 3.29 & 10 \\
\hline & & & & & Althaea rosea & Hollyhock & 3.49 & 1 \\
\hline & & & & & Althaea rugosa & Hollyhock & 3.26 & 10 \\
\hline & & & & & Malva sylvestris & Common mallow & 4.72 & 4 \\
\hline & & & & Sapindales & Pistachia chinensis & Chinese pistachio & 6.14 & 12 \\
\hline & & & & & Ruta graveolens & Rue & 1.07 & 7 \\
\hline & & Asterids & Basal & Ericales & Camellia sinensis & Camelia (Tea) & 0.47 & 10 \\
\hline & & & Euasterid II & Apiales & Anethum graveolens & Dill & 2.72 & 57 \\
\hline & & & & & Anthriscus cerefolium & Chervil & 3.70 & 57 \\
\hline & & & & & Apium graveolens & Celery & 4.45 & 2,57 \\
\hline & & & & & Coriandrum sativum & Coriander & 7.55 & 12 \\
\hline & & & & & Daucus carota & Carrot & 3.16 & $\begin{array}{l}1, \\
36-40, \\
57\end{array}$ \\
\hline & & & & & Petroselinum crispum & Parsley & 3.08 & 57 \\
\hline & & & & & Hedera helix & Ivy & 1.59 & 5 \\
\hline & & & & Asterales & Centaurea cyanus & Cornflower & 3.87 & 2 \\
\hline & & & & & Cichorum intybus & Chicory & 3.67 & $49-56$ \\
\hline
\end{tabular}


Table 1 (Continued)

\begin{tabular}{|c|c|c|c|c|c|c|c|c|}
\hline Class & Subclass & Group & Superorder & Order & Genus and species & Common name & $\begin{array}{l}\text { Mean relative } \\
\text { concentration }\end{array}$ & Study \\
\hline & & & \multirow{18}{*}{ Euasterid I } & \multirow{11}{*}{ Solanales } & Helianthus annuиs & Sunflower & 4.62 & 7,57 \\
\hline & & & & & Helianthus debilis & $\begin{array}{l}\text { Sunflower 'Vanilla } \\
\text { ice' }\end{array}$ & 5.16 & 11 \\
\hline & & & & & Lactuca sativa & Lettuce & 3.79 & $\begin{array}{l}13 \\
36-40\end{array}$ \\
\hline & & & & & Tithonia rotundifolia & $\begin{array}{l}\text { Mexican } \\
\text { sunflower }\end{array}$ & 4.79 & 1,10 \\
\hline & & & & & Ipomoea purpurea & $\begin{array}{l}\text { Purple morning } \\
\text { glory }\end{array}$ & 4.44 & 6,7 \\
\hline & & & & & Nemophila menziesii & Baby blue eyes & 4.02 & 3 \\
\hline & & & & & Lycopersicon esculentum & Tomato & 5.03 & 4,57 \\
\hline & & & & & Nicotiana glauca & $\begin{array}{l}\text { Yellow tree } \\
\text { tobacco }\end{array}$ & 5.05 & $\begin{array}{l}3,4,6, \\
7\end{array}$ \\
\hline & & & & & Nicotiana sylvestris & Tobacco & 3.70 & 3 \\
\hline & & & & & Solanum sisymbrifolium & Sticky Nightshade & 4.34 & 6 \\
\hline & & & & & Solanum tuberosum & Potato & 3.51 & $\begin{array}{l}36-40, \\
57\end{array}$ \\
\hline & & & & \multirow[t]{7}{*}{ Lamiales } & Mentha piperata & Peppermint & 5.26 & 3,12 \\
\hline & & & & & Mentha spicta & Spearmint & 6.72 & 13 \\
\hline & & & & & Salvia officinalis & Sage & 3.20 & 1 \\
\hline & & & & & Plantago major & Geater Plantain & 4.00 & $43-56$ \\
\hline & & & & & Plantago lanceolata & Ribwort Plantain & 3.92 & $43-56$ \\
\hline & & & & & Antirrhinum majus & Snapdragon & 8.71 & 3 \\
\hline & & & & & Digitalis ambigua & $\begin{array}{l}\text { Large Yellow } \\
\text { foxglove }\end{array}$ & 3.86 & 3 \\
\hline
\end{tabular}

Study numbers: 1-13; Experiments for this paper. 14; Garret et al. (1971). 15; Krouglev et al. (1997). 16-19; Choi et al. (1998), four treatments. 20-35; Abbazov et al. (1978), 16 soil types. 36-40; Freddricksson and Erikson (1957), four treatments. 41, Fuhrmann et al. (2002). 42, Fresquez et al. (1998). 43-49; Veresoglou et al. (1995), $2 \times 3$ treatments. 49-56, Veresoglou et al. (1996), $2 \times 4$ treatments. 57, Andersen (1967). 58, Sachdev et al. (1998).

Wallac 'Compugamma 1282' with appropriate blanks and background corrections. Experimental plants were, therefore, acutely exposed to ${ }^{85} \mathrm{Sr}$. Labelling of species took place in 13 batches (each of which was treated as a separate study in the REML analysis) using a randomised block design in an arena with light supplemented to c. $350 \mu \mathrm{Em}^{-1} \mathrm{~s}^{-1}$. Of the 103 species, 14 were also in the 66 species in literature studies. The whole Sr database (Table 1), therefore, included 155 taxa across 58 studies, derived from both the literature and experiment. Many taxa had multiple measurements in the database but some taxa had single measurements (Table 1).

Each of the 58 studies was used as a separate 'block' in the REML analysis and the species unit was used as the 'treatment' in the REML analysis, i.e. even if values for separate varieties were reported for a species they were coded as a single species. REML analysis was run on the statistical package Genstat for Windows 5th Ed. release 4.2 (VSN International, Oxford, UK) (Thompson and Welham, 2001) using the programme of Broadley et al. (1999, 2001, 2003, 2004). Defining blocks and treatments in this way accounts for the absolute differences in values arising from blocks (experimental conditions) to reveal mean relative values for the treatments (species). REML analyses can produce mean relative concentrations that are both positive and negative (Thompson and Welham, 2001). Following REML transformation a nested ANOVA was carried out coded using the updated phylogeny of the Angiosperm Phylogeny Group
(2003). The categories 'class', 'subclass', 'group' and 'superorder' (Table 1) were used nominally for units above the level of the order although the relationship between the Linnaean hierarchy they derive from and higher groups on recent phylogenies is contentious. Normality statistics used an Anderson-Darling test on Minitab 13.0 for Windows, in which standardised residual tests, correlation and linear regressions were also performed.

\section{Results}

Table 1 shows the mean relative concentrations of $\mathrm{Sr}$ in 155 species derived from REML analysis. There was significant inter-species variation overall, and in the 103 species labelled under similar conditions in experiments $(P<0.005$ for One-way ANOVAs). Mean relative concentrations for the 155 species failed the Anderson-Darling test for normality $\left(A^{2}=1.718 ; P<0.001 ;\right.$ Fig. 1$)$. However, as indicated by their large standardised residuals, removing seven species with distortingly large values (Silene chalcedonica, Antirrhinum majus, Papaver somniferum, Bergenia cordifolia, Passiflora caerulescens, Coriandrum sativum, Rumex sanguineus) and six points with distortingly small values (Allium tuberosum, Allium schoenoprasum, Maclura pomifera, Dianthus seguiri, Hypericum olympicum, Trifolium arvense) produced a core data set for 142 taxa with a normal distribution $\left(A^{2}=0.648\right.$; 


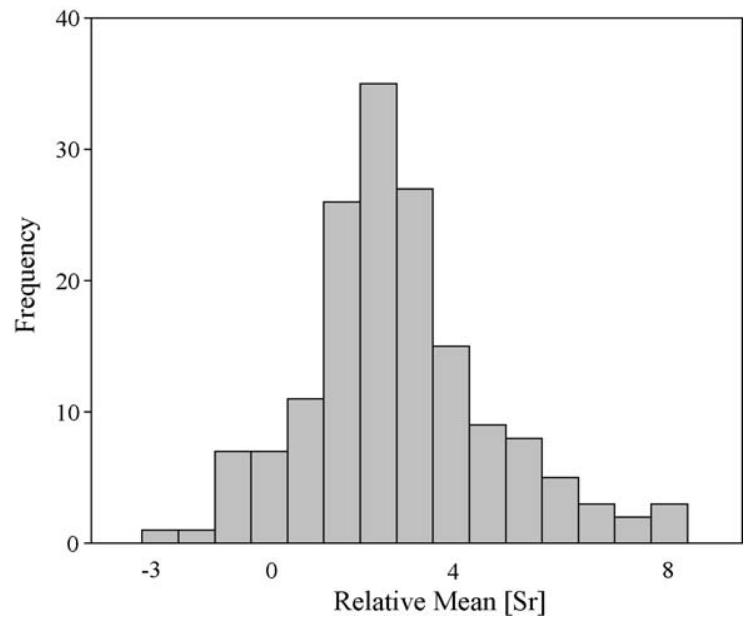

Fig. 1. The frequency distribution of mean relative $\mathrm{Sr}$ concentrations in 155 angiosperm species (15 divisions used, approximate mean relative $\mathrm{Sr}$ concentrations across divisions marked on $x$-axis).

$P=0.089$ ). All data were included in subsequent analysis because ANOVA is relatively robust to the assumption of normality.

There was a significant phylogenetic effect in the mean relative concentrations for $\mathrm{Sr}$ at all levels of the phylogenetic hierarchy down to the family (Table 2). There was a significant difference between non-Eudicots and Eudicots (Fig. 2a; Table 2), and the Monocots had the lowest mean relative Sr concentration of any 'Group' (Fig. 2b; Table 2). The mean relative $\mathrm{Sr}$ concentrations in the Commelinid monocots were significantly less than those of the Eudicots $(T=3.66$, d.f. $=135, P<0.001)$. Of the orders represented in the dataset the Cucurbitales, Lamiales, Saxifragales and Ranunculales had high mean relative Sr concentrations whilst the Asparagales, Liliales, Poales, Myrtales and Fabales had low mean relative $\mathrm{Sr}$ concentrations (Fig. 2c). Overall, the analysis indicated that about $15 \%$ of inter-taxa variation in $\mathrm{Sr}$ concentrations in plants was at the level of the order or above, $28 \%$ at the family or above, and a particularly large proportion of the variation $(47 \%)$ at the level of genus (Table 2).

The inter-species variation in $\mathrm{Sr}$ concentrations in plants is significantly related to inter-species variation in Ca concentration. There are 60 species in the database reported here

Table 2

Percent variation in Sums of Squares of Sr concentrations in plants and significance of ANOVA down the updated APG (2003) phylogeny

\begin{tabular}{lcrcrr}
\hline & SS $\times 10^{6}$ & $\%$ SS & Cumulative $\%$ & $F$-ratio & $P$-value \\
\hline Class & 5.3 & 2.48 & 2.52 & 17.52 & $<0.001$ \\
Subclass & 8.6 & 4.02 & 6.50 & 9.18 & $<0.001$ \\
Group & 3.17 & 1.48 & 7.98 & 7.22 & $<0.001$ \\
Superorder & 8.21 & 3.84 & 11.81 & 6.14 & $<0.001$ \\
Order & 8.2 & 3.83 & 15.64 & 2.19 & 0.002 \\
Family & 28.5 & 13.32 & 28.96 & 1.56 & 0.029 \\
Genus & 100 & 46.73 & 75.69 & 1.28 & 0.192 \\
Species & 37 & 17.29 & 100.00 & & \\
Total & 214 & & & & \\
\hline
\end{tabular}
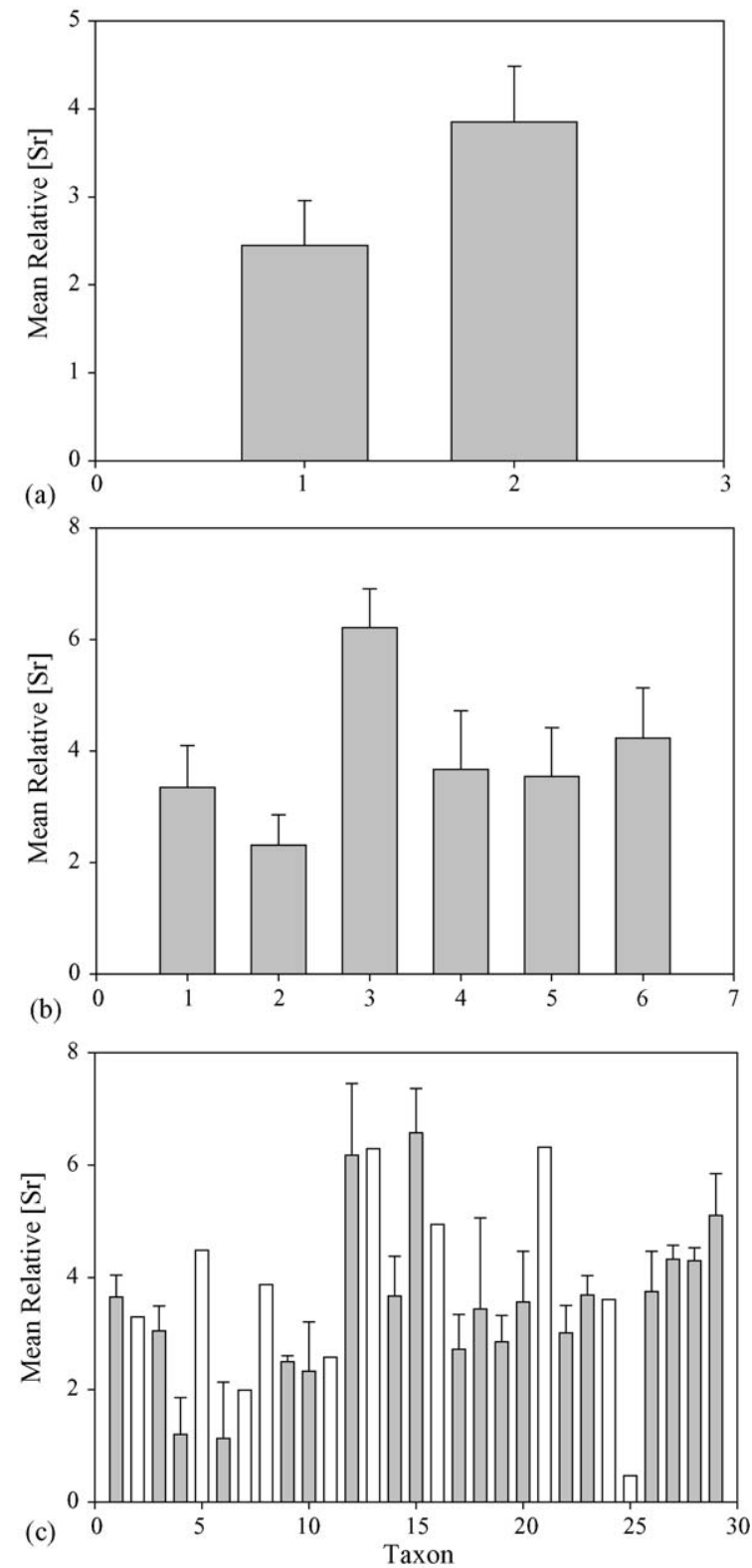

Fig. 2. Relative mean Sr concentrations in 'classes' (a), 'groups' (b) and orders (c) of flowering plants according to APG (2003) classification [(a) 'Classes' 1: non-Eudicots $(n=53), 2$ : Eudicots (102) (with $3 \times$ standard error). (b) 'Groups': 1: Magnoliids (7), 2: Monocots (46), 3: Basal Eudicots (4), 4: Core Eudicots (13), 5: Eurosids (56), 6: Euasterids (29) (with $3 \times$ standard error). (c) Orders: 1: Piperales (3), 2: Magnoliales (1), 3: Laurales (3), 4: Asparagales (3), 5: Dioscorales (1), 6: Liliales (6), 7: Arecales (2), 8: Commelinales (1), 9: Poales (28), 10: Zingiberales (3), 11: Alismatales (2), 12: Ranunculales (3), 13: Proteales (1), 14: Caryophyllales (13), 15: Saxifragales (4), 16: Geraniales (1), 17: Myrtales (4), 18: Malpighiales (5), 19: Fabales (15), 20: Rosales (8), 21: Curcurbitales (2), 22: Brassicales (11), 23: Malvales (4), 24: Sapindales (2),. 25: Ericales (1), 26: Apiales (7), 27: Asterales (6), 28: Solanales (8), 29: Lamiales (7) (with $1 \times$ standard error). Unshaded bars for orders where $n=1$ or 2].

that are included in Broadley et al.'s (2003) dataset of relative mean values for 206 species in the literature. Fig. 3a shows that there is a significant relationship between the relative mean $\mathrm{Ca}$ and relative mean $\mathrm{Sr}$ concentrations in these taxa 

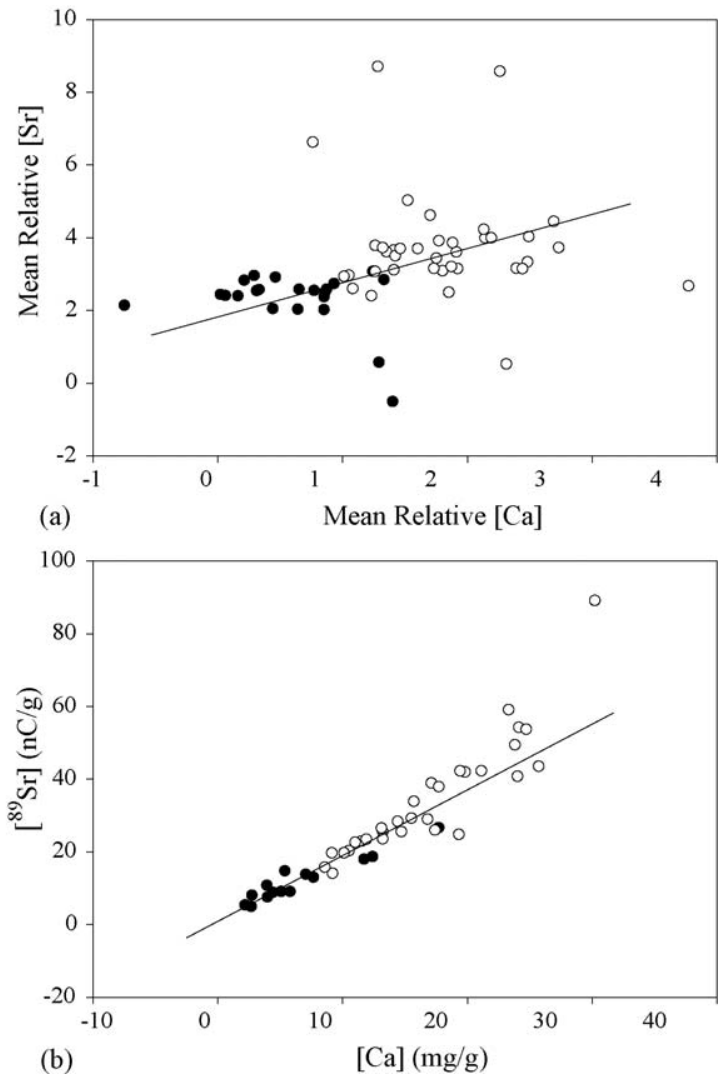

Fig. 3. (a) The relationship between mean relative $\mathrm{Sr}$ and mean relative $\mathrm{Ca}$ concentrations in 60 angiosperm taxa using $\mathrm{Sr}$ from Table 1 and $\mathrm{Ca}$ from Broadley et al.'s (2003) literature dataset (closed dots: non-Eudicots, open dots: Eudicots. $R^{2}=36.5 \%, F=4.14, P=0.046$ ). (b) The relationship between $\mathrm{Sr}$ and $\mathrm{Ca}$ concentrations in 44 angiosperm taxa from Andersen's (1967) dataset (closed dots: non-Eudicots, open dots: Eudicots).

$\left(R^{2}=36.5 \%, F=4.14, P=0.046\right)$. Cucurbita maxima, Antirrhinum majus and Papaver somniferum have distortingly high Sr to Ca ratios and Allium schoenopraesum and Zingiber officinale particularly low ones; removing these five points that have large standardised residuals improved the relationship $\left(R^{2}=56 \%, F=29.7, P=0.000\right)$. The relationship between $\mathrm{Ca}$ and $\mathrm{Sr}$ in Fig. 3a is similar to but not as close as that previously reported (e.g. Andersen, 1967 for 44 species, Fig. 3b). Fig. 3a, however, includes more diverse species than any previous inter-species comparison of $\mathrm{Ca}$ :Sr ratios and the variety of conditions used to produce the data may have increased variability. Fig. 3b highlights that although $\mathrm{Ca}: \mathrm{Sr}$ ratios in non-Eudicots and Eudicots are similar they take up these elements to different concentrations.

\section{Discussion}

Much research subsequent to the accident at Chernobyl demonstrated the importance of plant species other than staple crops to assessments of radiation doses to humans (Desmet et al., 1990). There is also increased interest in esti- mating radiological impacts to flora because of proposals to reform assessments which assume that if humans are adequately protected then so are all other organisms (Strand and Larsson, 2001). Further, phytoremediation is increasingly being considered as a component of decontamination and decommissioning procedures and is more nearly possible for ${ }^{90} \mathrm{Sr}$ than other radioecologically significant isotopes (Willey et al., 2001; Fuhrmann et al., 2002). In all these instances, knowledge of $\mathrm{Sr}$ concentrations in a wide range of species is desirable. Table 1 is the most comprehensive inter-species comparison of $\mathrm{Sr}$ concentrations in plants yet reported. Care must be taken, however, in interpreting the mean relative $\mathrm{Sr}$ concentrations because of both the numerous variables that might effect relative $\mathrm{Sr}$ concentrations in plants and the sampling biases in species represented. For example, REML analysis, using absolute concentrations for species in different datasets, statistically accounts for the effects of different exposure conditions and estimates relative mean concentrations for each species in the datasets in effect a rank order - but the actual rank order of species might not be identical under all conditions. This is because there might be interactions between rank order and, for example, ecological variables (Ehlken and Kirchner, 1996), growth phase at the time of Sr application (Choi et al., 1998), mycorrhizal status (Riesen and Brunner, 1996) or exposure times to $\mathrm{Sr}$. So, the relative mean values in Table 1 represent a general estimate for relative mean $\mathrm{Sr}$ concentrations in plants across a variety of conditions and exposures (probably at 'steady-state' uptake and not) rather than for any specific set of uptake conditions. There is also sampling bias because although we attempted to increase the phylogenetic spread of data by complementing that reported in the literature (which was not collected with phylogenetic analysis in mind) with species in our experiments, the availability of fast growing herbs and a wish to try to include significant food crops meant that the dataset is not phylogenetically balanced as it does not reflect exactly the actual number of species in the different phylogenetic groups.

The effects of some of these potentially confounding factors can, however, be estimated. First, it is possible to investigate preliminarily the significance of exposure time by comparing concentrations between species in a dataset of acute exposure (such as the experiments reported here) and a dataset of chronic, 'steady-state', exposure. The dataset of chronic exposure with the most species in common with the experiments reported here is that of Andersen (1967). Following $\log _{10}$-transformation of absolute values to account for the wide range of concentrations, for nine species in common (Allium cepa, Allium schoenopraesum, Beta vulgaris, Trifolium repens, Trifolium pratense, Brassica oleracea, Daucus carota, Lactuca sativa, Lycopersicon esculentum) there is a positive correlation ( $r=0.714, P=0.008)$ between concentrations after acute (experiments reported here) and chronic (steady-state) exposures (Andersen, 1967). If acute exposure is in the exponential growth phase (as it was in our experiments), because much $\mathrm{Sr}$ uptake occurs during this 
phase (Weaver et al., 1981) the relative concentrations it produces might be expected to be related to those following chronic exposures. Second, Broadley et al. (2003) tested whether or not phylogenetic sampling bias affected the detection of a phylogenetic effect in Ca concentrations in plants. They were able to find, with a taxonomically unbalanced literature data set of 206 taxa, phylogenetic effects in $\mathrm{Ca}$ concentrations in plants that were the same as those found in a phylogenetically-balanced experimentally-derived set of $\mathrm{Ca}$ concentrations in 117 species. The $\mathrm{Sr}$ data set reported here includes 155 taxa spread across the higher taxonomic groups and, therefore, seems likely to reveal phylogenetic effects at least at the higher taxonomic levels. Differences in Sr concentration have previously been related only to taxonomy at the family level (Andersen, 1967; Breulmann et al., 1999). The analysis presented here is, therefore, the first scientific attempt to describe phylogenetic effects on $\mathrm{Sr}$ concentrations in plants and Table 1 provides a general estimate of relative mean $\mathrm{Sr}$ concentrations relativised across a variety of conditions and exposures that is suitable for investigating phylogenetically. Specific investigations under particular conditions or exposures might not produce the same relative concentrations as in Table 1 and are likely to be less useful for investigating the general effects of phylogeny.

In comparison to other studies of ion concentrations in plants down to the ordinal level, the phylogenetic effect for $\mathrm{Sr}$ of $14.5 \%$ is greater than that for $\mathrm{P}(6.8 \%)$ and $\mathrm{N}(3.3 \%)$ (Broadley et al., 2004), similar to that for Cs (15\%) (Willey et al., 2005) approaching that for $\mathrm{Pb}(20 \%), \mathrm{Cr}(23 \%), \mathrm{Cu}$ (24\%), Cd (27\%) (Broadley et al., 2001) and $\mathrm{Na}(23 \%)$ (Broadley et al., 2004), but significantly less than that for $\mathrm{Zn}$ (44\%), Ni (46\%) (Broadley et al., 2001), Ca (63\%) (Broadley et al., 2003) and K (49\%) (Broadley et al., 2004). For Sr there are significant differences in mean relative concentration between non-Eudicots and Eudicots (Figs. 2a and 3a), and between the Commelinid monocot and Eudicots, just as for $\mathrm{Ca}$ there were differences between the Commelinid monocots and Eudicots (Broadley et al., 2003). For Ca such differences have been ascribed to differences in root cation exchange capacities (e.g. White and Broadley, 2003) and the Sr patterns described here are consistent with this, and with Nisbet and Woodman's (2000) finding that cereals (Poales in the Commelinid monocots) have particularly low transfer factors for ${ }^{90} \mathrm{Sr}$. Testing whether or not root cation exchange capacity is related to differences in $\mathrm{Sr}$ concentrations might, therefore, be a fruitful avenue of research for attempts to elucidate the controlling mechanisms on ${ }^{90} \mathrm{Sr}$ concentrations in plants. There are further significant phylogenetic effects down to the family level (Table 2). Specific tests between groups at each level necessitate more extensive sampling than is often present in Table 1, but of the orders represented in the dataset the Cucurbitales, Lamiales, Saxifragales and Ranunculales had high mean relative $\mathrm{Sr}$ concentrations (Fig. 2c). This indicates that these plants might merit particular attention in assessments of doses to flora and in the search for plants suitable for phytoremediation and phytomonitoring of ${ }^{90} \mathrm{Sr}$. The Asparagales, Liliales, Poales, Myrtales and Fabales had low mean relative Sr concentrations (Fig. 2c) and might be a source of 'safe crops' for ${ }^{90} \mathrm{Sr}$ contaminated soil. Broadley et al. (2003) noted that concentrations of $\mathrm{Ca}$ in the Cucurbitales were high and in the Poales and Myrtales were low, relative to the other orders in their dataset.

$\mathrm{Sr}$ and $\mathrm{Ca}$ are chemically closely related and there are numerous reports that they behave as chemical analogues in a variety of plants (e.g. Andersen, 1967; Bauer et al., 1998; Knoblauch et al., 2001). This accounts for the fact that $\mathrm{Sr}$, like $\mathrm{Ca}$, is often located apoplastically in plants, is found in the highest concentrations in leaves (Von Firks et al., 2002) and is transported primarily in the xylem (Herren and Feller, 1997). The phylogenetic signal for $\mathrm{Sr}$ has clear similarities with that of $\mathrm{Ca}$, including essentially normal frequency distributions, differences between non-Eudicots and Eudicots, and between some orders. Further, if the literature-derived relative mean concentrations of Broadley et al. (2003) for Ca are plotted, for the 60 species in common, against those for $\mathrm{Sr}$ reported here there is a clear positive relationship (Fig. 3a). This relationship is similar to that reported by Andersen (1967) for 44 species, which is the most extensive direct comparison of $\mathrm{Sr}: \mathrm{Ca}$ concentrations reported and which has recently been a basis for discussions of Sr:Ca uptake mechanisms (White, 2005). In fact, Andersen's data, if classified into non-Eudicots and Eudicots, shows the same phylogenetic differences as the REML-derived relative mean $\mathrm{Sr}$ and $\mathrm{Ca}$ values (Fig. 3b). Although Andersen's data contributed to the REML analysis it contained only 16 of the 60 species in Fig. 3a. Overall, given the enormous variety of experimental conditions, including acute and chronic doses, that Fig. 3a is based on, the somewhat greater variation than in Fig. $3 \mathrm{~b}$ is not perhaps surprising and lends support to the known strong relationship between $\mathrm{Ca}$ and $\mathrm{Sr}$ in plants. Direct comparisons of relative means for orders reported here for $\mathrm{Sr}$ and by Broadley et al. (2003) for $\mathrm{Ca}$ cannot be made because of the different orders used in the different REML procedures but Broadley et al. (2003) noted the highest $\mathrm{Ca}$ uptake in the Cucurbits and the lowest in the Ericales, as was the case for Sr here. Given that there were few representatives from these orders in either the dataset reported here for $\mathrm{Sr}$ or that of Broadley et al. (2003) for $\mathrm{Ca}$, their uptake of $\mathrm{Sr}$ and $\mathrm{Ca}$ might usefully be investigated further. Broadley et al. (2003) reported low $\mathrm{Ca}$ in the Poales and Myrtales, as was the case for Sr here. We suggest that, in instances when plants with particularly low Sr uptake are important, it might be worth further investigating Sr uptake in these orders. In the $\mathrm{Sr}$ data reported here relative mean concentrations in the Fabales and Brassicales, in particular, are lower than those reported for Ca by Broadley et al. (2003). Investigations of $\mathrm{Ca}: \mathrm{Sr}$ in the Fabales and Brassicales might help to establish if these differences are real or the effects on rank order of the different species in the datasets.

The results reported here for $\mathrm{Sr}$, though similar to, are not, as might have been expected, identical to those for $\mathrm{Ca}$. There are several reasons why this might be the case. First, the acute 
$\mathrm{Sr}$ exposures used in experiments here produce related but not identical relative concentrations to chronically exposed plants. During acute exposures, it is less likely, for example, that uptake has reached 'steady-state' in all species. Efforts were made to ensure homogenous ${ }^{85} \mathrm{Sr}$ exposure of roots, and acute exposure occurred during the exponential phase but there is no a priori reason why concentrations arising from acute exposures should be identical to those arising from chronic exposures. It is notable, however, that acute exposures to $\mathrm{Sr}$ are of radioecological significance in their own right, particularly during immediate responses to releases of radioisotopes, and produce concentrations that are positively related to those from chronic exposure. Second, there might also be differences between $\mathrm{Sr}$ and $\mathrm{Ca}$ because of the fact that the REML process accounts for differences due to species and study but not differences arising from their interaction. $\mathrm{Ca}: \mathrm{Sr}$ ratios in plants in general reflect $\mathrm{Ca}: \mathrm{Sr}$ ratios in soil solution (rather than total Ca:Sr in soil), and this ratio can vary significantly with soil type even when the same total amounts are present (Veresoglou et al., 1996). Thus, interactions between soil variables such as $\mathrm{Ca}: \mathrm{Sr}$ in solution and species rank order would need to be accounted for before concluding definitively that the phylogenetic signals of $\mathrm{Ca}$ and $\mathrm{Sr}$ are not identical. However, given the much wider taxonomic spread in Fig. 3a (Fig. $3 \mathrm{~b}$ is derived primarily from four families), and especially in Table 1, compared with any previously published $\mathrm{Sr}$ data, and that the orders with high and low relative mean $\mathrm{Sr}$ concentrations were not all the same as those noted for $\mathrm{Ca}$ by Broadley et al. (2003), we suggest that it is worth considering a third possibility that $\mathrm{Ca}: \mathrm{Sr}$ discrimination might not be identical in all plants. There are reports, primarily from the biogeochemical literature, that $\mathrm{Sr}$ isotopes are not exact chemical analogues of $\mathrm{Ca}$ in ecosystems. This is borne out by reports that discrimination between $\mathrm{Sr}$ and $\mathrm{Ca}$ can differ with trophic level (Blum et al., 2000) and that in forest cycling of $\mathrm{Sr}$ and $\mathrm{Ca}$ differences can be detected (Poswa et al., 2000). White and Broadley (2003) have recently shown that different ratios of symplast/apoplast uptake between $\mathrm{Sr} / \mathrm{Ca}$ might produce different concentration ratios of $\mathrm{Sr} / \mathrm{Ca}$ in plant shoots. Differences in discrimination have also been reported, for example, between other chemically similar elements such as $\mathrm{Cs}$ and $\mathrm{K}$ in different orders of plants (Broadley and Willey, 1999).

\section{Conclusion}

Sr concentrations in plants are essentially normally distributed but because in the REML procedure used here raw values are $\log _{\mathrm{e}}$-transformed, Fig. 1 offers support to the conclusion that $\mathrm{Sr}$ concentrations in plant species are, more specifically, $\log _{\mathrm{e}}$ normally distributed (e.g. Sheppard and Evenden, 1997). The characteristics of this distribution might be useful in parametric models intended for numerous plant species. Significant differences in $\mathrm{Sr}$ concentrations have been reported from a single species grown on differ- ent substrates (e.g. Andersen, 1967; Abbazov et al., 1978) but we conclude that inter-species differences in $\mathrm{Sr}$ uptake from a single substrate are also significant. This is consistent with the findings of Nisbet and Woodman (2000) who, in an extensive review of ${ }^{90} \mathrm{Sr}$ transfer factors, noted that ${ }^{90} \mathrm{Sr}$ transfer factors differed by an order of magnitude between soil types and by a greater amount between species. Modellers of ${ }^{90} \mathrm{Sr}$ availability in soil such as Roca et al. (1997) have also noted that, in addition to soil factors, plant factors might be important to predicting soil-to-plant transfer. The mean relative concentrations reported here might provide a starting point for integrating the differences between all plant species in uptake of ${ }^{90} \mathrm{Sr}$ with the differences in ${ }^{90} \mathrm{Sr}$ availability in soils and should enable radioecological models to incorporate a wider range of plant taxa than has previously been possible for ${ }^{90} \mathrm{Sr}$, in particular, for acute exposures.

Analysis using a recent phylogeny clearly showed that plant species not only take up Sr to different concentrations but that uptake by each species is not independent because it is linked through phylogeny. In soil-to-plant transfer models it should, therefore, be assumed neither that plant species just reflect soil ${ }^{90} \mathrm{Sr}$ availability nor that they behave independently. The phylogenetic effect suggests which plant species might merit particular attention in food production systems and be useful in assessing doses to flora from ${ }^{90} \mathrm{Sr}$. Species with high uptake of ${ }^{90} \mathrm{Sr}$ might be useful sentinels in biomonitoring, perhaps particularly in food production systems, but the frequency distribution in Fig. 1 indicates that almost any of the species in Table 1 might be used as biomonitors to collect data for parametric models. The high uptake noted in particular orders and species of plants might help increase phytoremediation rates for ${ }^{90} \mathrm{Sr}$ as many species in these groups have not previously been assessed and the increases in soil-to-plant transfer necessary to make phytoremediation viable, at two- or three-fold, are less than for other radioisotopes such as ${ }^{137} \mathrm{Cs}$ (Fuhrmann et al., 2002). Alternatively, the low uptake of other orders might be useful in identifying safe crops for contaminated soils. Given the potential sources of variation between studies, the Sr phylogenetic signal reported here is similar to that previously reported for $\mathrm{Ca}$, but we conclude that $\mathrm{Ca}: \mathrm{Sr}$ ratios in uptake in a number of orders for which few data have previously been reported, might be worth further investigation - to at least put the assumption of identical behaviour of $\mathrm{Sr}$ and $\mathrm{Ca}$ in plants on a more certain phylogenetic foundation. Overall, the results reported here for Sr suggest that it might be useful for radioecologists to investigate phylogenetic effects in plant concentrations of other radioisotopes.

\section{Acknowledgements}

We would like to thank the UK Food Standards Agency for funding this work, Judy Brown for technical assistance with radioanalysis and Dr. Andrew Meade of the University of Warwick for developing the Genstat programme. 


\section{References}

Abbazov, M.A., Dergunov, I.D., Mikulin, R.G., 1978. Effect of soil properties on the accumulation of strontium- 90 and cesium-137 in crops. Pochvov 2, 25-29.

Ackerley, D.D., 1999. Comparative plant ecology and the role of phylogenetic information. In: Press, M.C., Scholes, J.D., Barker, M.G. (Eds.), Physiological Plant Ecology. Blackwell Science, Oxford, UK, pp. 391-414.

Albert, V.A., Williams, S.E., Chase, M.W., 1992. Carnivorous plants: phylogeny and structural evolution. Science 257, 1491-1495.

Andersen, A.J., 1967. Investigations on the plant uptake of fission products from contaminated soils. 1. Influence of plant species and soil types on the uptake of radioactive strontium and caesium. Risö Report No. 170. Risö Denmark, Danish Atomic Energy Commission.

Anspaug, H.L.R., Catlin, R.J., Goldman, M., 1988. The global impact of the Chernobyl reactor accident. Science 242, 1513-1519.

APG (Angiosperm Phylogeny Group) II, 2003. An update of the Angiosperm Phylogeny Group classification for the orders and families of flowering plants: APG II. Bot. J. Linn. Soc. 141, 399-436.

Askbrant, S., Sandalls, J., 1998. Root uptake of ${ }^{137} \mathrm{Cs}$ and ${ }^{90} \mathrm{Sr}$ by rye grass on various soils in the CIS. J. Environ. Radioact. 38, 85-95.

Ban-nai, T., Muramatsu, Y., 2002. Transfer factors of radioactive Cs, $\mathrm{Sr}, \mathrm{Mn}, \mathrm{Co}$ and $\mathrm{Zn}$ from Japanese soils. J. Environ. Radioact. 63, 251-264.

Bauer, C.S., Plieth, C., Bethmann, B., Popescu, O., Hansen, U.-P., Simonis, W., Schöknecht, G., 1998. Strontium induced repetitive calcium spikes in a unicellular green alga. Plant Phys. 117, 545-557.

Beresford, N.A., Broadley, M.R., Howard, B.J., Barnett, C.L., White, P.J., 2004. Estimating radionuclide transfer to wild species-data requirements and availability for terrestrial ecosystems. J. Radiol. Prot. 24, A89-A103.

Blum, J.D., Taliaferro, E.H., Weisse, E.T., Holmes, R.T., 2000. Changes in $\mathrm{Sr} / \mathrm{Ca}, \mathrm{Ba} / \mathrm{Ca}$ and ${ }^{87} \mathrm{Sr} /{ }^{86} \mathrm{Sr}$ ratios between trophic levels in two forest ecosystems in the northeastern USA. Biogeochemistry 49, 87-101.

Breulmann, G., Ogino, K., Markert, B., Leffler, U.S., Herpin, U., Welkert, V., Konschak, R., Kikugawa, Y., Ohkubo, T., 1999. Comparison of chemical elements in Dipterocarpaceae and Euphorbiaceae from a tropical rain forest in Sarawak, Malaysia. Sci. Total Environ. 225, 231-240.

Broadley, M.R., Willey, N.J., 1999. A comparison of caesium uptake by 30 plant species. Environ. Pollut. 97, 11-15.

Broadley, M.R., Willey, N.J., Mead, A., 1999. A method to assess taxonomic variation in shoot caesium concentration among flowering plants. Environ. Pollut. 106, 341-349.

Broadley, M.R., Willey, N.J., Wilkins, J., Baker, A.J.M., Mead, A., White, P.J., 2001. Phylogenetic variation in heavy metal accumulation in angiosperms. New Phytol. 152, 9-27.

Broadley, M.R., Bowen, H.C., Cotterill, H.L., Hammond, J.P., Meacham, M.C., Mead, A., White, P.J., 2003. Variation in the shoot calcium content of angiosperms. J. Exp. Bot. 54, 1-16.

Broadley, M.R., Bowen, H.C., Cotterill, H.L., Hammond, J.P., Meacham, M.C., Mead, A., White, P.J., 2004. Phylogenetic variation in the shoot mineral concentration of angiosperms. J. Exp. Bot. 55, 321336.

Choi, Y.H., Lee, C.W., Kim, S.R., Lee, J.H., Jo, J.S., 1998. Effect of application time of radionuclides on their uptake by Chinese cabbage and radish. J. Environ. Radioact. 39, 183-198.

Desmet, G., Nassimbeni, P., Belli, M. (Eds.), 1990. Transfer of Radionuclides in Natural and Semi-Natural Environments. Elsevier Applied Science, London.

Doyle, J., 1998. Phylogenetic perspectives on nodulation: Evolving views of plants and symbiotic bacteria. Trends Plant Sci. 3, 473-478.

Ehleringer, J.R., Monson, R.K., 1993. Evolutionary and ecological aspects of photosynthetic pathway variation. Annu. Rev. Ecol. Sys. 24, $411-439$.
Ehlken, S., Kirchner, G., 1996. Seasonal variations in soil-to-grass transfer of fallout strontium and cesium and of potassium in North German soils. J. Environ. Radioact. 33, 147-181.

Fitter, A.H., Moyerson, B., 1996. Evolutionary trends in root-microbe symbioses. Philos. Trans. R. Soc. Series B 351, 1375-1376.

Freddricksson, L., Erikson, B., 1957. Studies on soil-plant-animal interrelationships with respect to fission products. Part A. Plant uptake of ${ }^{90} \mathrm{Sr}$ and ${ }^{137} \mathrm{Cs}$ from soils. Prog. Nucl. Ener. Series XII 1, 500-533.

Fresquez, P.R., Armstrong, D.R., Mullen, M.A., Naranjo Jr., L., 1998. The uptake of radionuclides by beans, squash and corn growing in contaminated alluvial soils at Los Alamos National Laboratory. J. Environ. Sci. Health B33, 99-122.

Frissel, M.J., 1992. An update of the recommended soil-to-plant transfer factors of Sr-90, Cs-137 and transuranics. In: eighth Report of the IUR Working Group on Soil-Plant Transfer, I.U.R. Banlan, Belgium, pp. 16-25.

Fuhrmann, M., Lasat, M.M., Ebbs, S.D., Kochian, L.V., Cornish, J., 2002. Uptake of cesium-137 and strontium-90 from contaminated soil by three plant species: Application to phytoremediation. J. Environ. Qual. 31, 904-909.

Garret Jr., A.R., Cummings, S.L., Regnier, J.E., 1971. Accumulation of ${ }^{137} \mathrm{Cs}$ and ${ }^{85} \mathrm{Sr}$ by florida forages in a uniform environment. Health Phys. 21, 67-70.

Harvey, P.H., Brown, A.J.L., Maynard-Smith, J., Nee, S., 1996. New Uses for New Phylogenies. Oxford University Press, Oxford, UK.

Herren, T., Feller, U., 1997. Transport of cadmium via xylem and phloem in maturing wheat shoots: comparison with translocation of zinc, strontium and rubidium. Ann. Bot. 80, 623-628.

Jansen, S., Broadley, M.R., Robbrecht, E., Smets, E., 2002. Aluminium hyperaccumulation in angiosperms: a review of its phylogenetic significance. Bot. Rev. 68, 235-269.

Karavaeva, Y.N., Kulinov, N.V., Molchanova, I.V., Pozolotina, V.N., Yushkov, P.I., 1994. Accumulation and distribution of long-lived radionuclides in the forest ecosystems of the Kyshtym accident zone. Sci. Total Environ. 157, 147-151.

Kashparov, V.A., Oughton, D.H., Zvarich, S.I., Protsak, V.P., Levchuk, S.E., 1999. Kinetics of fuel particle weathering and ${ }^{90} \mathrm{Sr}$ mobility in the Chernobyl $30 \mathrm{~km}$ exclusion zone. Health Phys. 76, 251-259.

Kliashtorin, A.L., Tikhomirov, F.A., Shcheglov, A.I., 1994. Lysimetrical study of radionuclides in the forests around the Chernobyl nuclear power plant. J. Environ. Radioact. 24, 81-90.

Knoblauch, M., Peters, W.S., Ehlers, K., Bel von, A.J.E., 2001. Reversible calcium regulated stopcocks in legume sieve tubes. Plant Cell 13, 1221-1230.

Krouglev, S.V., Filipas, A.S., Alexakhin, R.M., Arkhipov, N.P., 1997. Long-term study on the transfer of ${ }^{137} \mathrm{Cs}$ and ${ }^{90} \mathrm{Sr}$ from Chernobylcontaminated soil to grain crops. J. Environ. Radioact. 34, 267-286.

Kuzoff, H., Gasser, C.S., 2000. Recent progress in reconstructing angiosperm phylogeny. Trends Plant Sci. 5, 330-336.

Marschner, H., 1995. The Mineral Nutrition of Plants, second ed. Academic Press, London.

Nisbet, A.F., Woodman, R.F.M., 2000. Soil-to-plant transfer factors for radiocaesium and radiostrontium in agricultural systems. Health Phys. 78, 279-288.

Nishita, H., Steen, A.J., Larson, K.H., 1958. The release of Sr-90 and Cs137 from Vina loam upon prologued cropping. Soil Sci. 86, 195-201.

Poston, T.M., Jaquish, R.E., Antonio, E.J., Patton, G.W., 1998. Strontium90 in alfalfa (Medicago sativa) around the Hanford Site in Southwestern Washington State: an evaluation of surveillance data. J. Environ. Radioact. 39, 87-105.

Poswa, A., Dambrine, E., Pollier, B., Atteia, O., 2000. A comparison between $\mathrm{Ca}$ and $\mathrm{Sr}$ cycling in forest ecosystems. Plant Soil 225, 229-310.

Riesen, T.K., Brunner, I., 1996. Effect of ectomycorrhizae and ammonium on ${ }^{134} \mathrm{Cs}$ and ${ }^{85} \mathrm{Sr}$ uptake into Picea abies seedlings. Environ. Pollut. $93,1-8$. 
Roca, M.C., Vallejo, V.R., Roig, M., Tent, J., Vidal, M., Rauret, G., 1997. Prediction of cesium-134 and strontium-85 crop uptake based on soil properties. J. Environ. Qual. 26, 1354-1362.

Romney, E.M., Neel, J.W., Nishita, J., Olafson, J.H., Larson, K.H., 1957. Plant uptake of Sr-90, Y-91, Ru-106, Cs-137 and Ce-144 from soils. Soil Sci. 83, 369-376.

Sachdev, P., Sachdev, M.S., Deb, D.L., 1998. The uptake and transfer of caesium-137, strontium-90 and zinc-65 from soil to food crops in tropical environment. J. Nucl. Agric. Biol. 27, 1-9.

Sheppard, S.C., Evenden, W.G., 1997. Variation in transfer factors for stochastic models: soil-to-plant transfer. Health Phys. 72, 727733.

Soltis, P.S., Soltis, D.E., Chase, M.W., 1999. Angiosperm phylogeny inferred from multiple genes as a research tool for comparative biology. Nature 402, 402-404.

Strand, P., Larsson, C.-M., 2001. Delivering a framework for the protection of the environment from ionising radiation. In: Howard, B., Bréchignac, F. (Eds.), Radioactive Pollutants-Impact on the Environment. EDP Sciences, France, pp. 131-145.

Sugden, A.M., Jasney, B.R., Culotta, E., Pennisi, E., 2003. Charting the evolutionary history of life. Science 300, 1691-1692.

Thompson, R., Welham, S.J., 2001. REML analysis of mixed models. In: Payne, R.W. (Ed.), The Guide to Genstat-Part 2. Statistics. VSN International, Oxford, pp. 413-503.

Tikhomirov, F.A., Shcheglov, A.I., 1994. Main investigation results on the forest radioecology in the Kyshtym and Chernobyl accident zones. Sci. Total Environ. 157, 45-57.
Von Firks, Y., Rosén, K., Sennerby-Forse, L., 2002. Uptake and distribution of ${ }^{137} \mathrm{Cs}$ and ${ }^{90} \mathrm{Sr}$ in Salix viminalis plants. J. Environ. Radioact. $63,1-14$.

Veresoglou, D.S., Barbayiannis, N., Zalidis, G.C., Kalpakis, S., Batianis, E., 1995. Transfer factors for $\mathrm{Sr}$ as influenced by species $\mathrm{Ca}$ uptake and soil Ca availability. Plant Soil 175, 225-232.

Veresoglou, D.S., Barbayiannis, N., Matsi, T., Anagnostopoulos, C., Zalidis, G.C., 1996. Shoot $\mathrm{Sr}$ concentrations in relation to shoot Ca concentrations and to soil properties. Plant Soil 178, 95-100.

Walker, R.B., Gessel, S., Held, E., 1997. The ecosystem study on Rongelap Atoll. Health Phys. 73, 223-233.

Weaver, C.M., Harris, N.D., Fox, L.R., 1981. Accumulation of strontium and caesium by kale as a function of plant age. J. Environ. Qual. 10, 95-98.

White, P.J., 1998. Calcium channels in the plasma membrane of root cells. Ann. Bot. 81, 173-183.

White, P.J., 2001. The pathways of calcium movement to the xylem. J. Exp. Bot. 52, 891-899.

White, P.J., 2005. Calcium. In: Broadley, M.R., White, P.J. (Eds.), Plant Nutritional Genomics. Blackwell Publishing, Oxford, pp. 66-86.

White, P.J., Broadley, M.R., 2003. Calcium in plants. Ann. Bot. 92, 487-511.

Willey, N.J., Hall, S.C., Mudiganti, A., 2001. Assessing the potential of phytoextraction at a site in the UK contaminated with ${ }^{137}$ Cs. Int. J. Phytorem. 3, 321-333.

Willey, N.J., Tang, S., Watt, N.R., 2005. Predicting inter-taxa differences in plant uptake of 134/137Cs. J. Environ. Qual. 34, 1478-1489. 